\title{
Perspektiv
}

\section{Lagstadgad kunskap Om svensk museipolitik och forskning}

\author{
Klas Grinell \& Anders Högberg
}

Vad betyder museilagens betoning av kunskapsuppbyggnad för museers forskning? Hur ser relationerna mellan forskning, kunskap och museer ut i museilagens Sverige? Om detta handlar denna text. Men först en liten inringning av det sammanhang museilagen kom till i.

\section{DEN SVENSKA MUSEIPOLITIKENS HISTORIA}

Under vintern 2016-2017 rasade det vi kallade museidebatten i Sverige (Högberg 2016). Ett centralt spår handlade om vad kunskap är, och vilken slags kunskap museer ska ägna sig åt. Flera framträdande debattörer framställde det som om den rådande miljöpartistiska kulturpolitiken trängt ut kunskapen från museerna (se exempelvis Hakelius 2017).

För att förstå museernas roll som offentlig kunskapsinstitution behövs dock ett djupare historiskt perspektiv. Svensk museipolitik har nämligen en nästan hundraårig historia där flera av de förutsättningar som skylldes på Miljöpartiet och kulturministern Alice Bah Kuhnke är resultatet av utvecklingslinjer som ristades långt innan Miljöpartiet ens var bildat (Svanberg 2009, 2015; Hyltén-Cavallius \& Svanberg 2016; Lund 2016).

Relationen mellan forskning och museer kan följas genom en handfull offentliga utredningar och politiska propositioner, tabell 1 .
Det skulle leda allt för långt att gå in i detaljer kring varje av dessa offentliga utredningar och de propositioner som de resulterat i. Det kan räcka med att påpeka hur den samtida svenska museipolitiken fortfarande bär starka spår av 1965 års musei- och utställningssakkunniga, som arbetade inom ramen för den stora kulturpolitiska utredning som resulterade i den första tydligt institutionaliserade svenska kulturpolitiken 1974.

I den moderna museisynen låg ett starkt fokus på folkbildning och professionaliserad kulturvård, medan forskning skulle skötas av universiteten (med undantag för naturvetenskapliga museer som exempelvis Naturhistoriska riksmuseet som har en omfattande forskningsverksamhet). Redan på 1970-talet gjordes alltså en uppdelning mellan universiteten som forskande och museerna som förmedlande. De grundförutsättningar för svensk kulturpolitisk organisering som lades då kan i stora drag fortfarande sägas rama in samtidens kulturinstitutioner (Näsman 2014).

Den brist på forskarkunnig personal inom museerna som i 2016-2017 års museidebatt lyftes fram som ett normkritiskt förakt för kunskap (se diskussion i Högberg 2016), har alltså en längre historia än det parti som där ställdes till ansvar för den rådande situationen.

I den stora kulturpolitiska propositionen från 1974 nämndes "åtgärder för att bevara 
SOU 1922:11 Betänkande med förslag till lag angående kulturminnesvård samt organisation av kulturminnesvården

SOU 1972:45 Kulturminnesvård. Betänkande avgivet av 1965 års musei och utställningssakkunniga SOU 1973:5 Museerna. Betänkande avgivet av 1965 års musei- och utställningssakkunniga SOU 1974:43 Utställningar. Betänkande avgivet av 1965 års musei- och utställningssakkunniga SOU 1981:30 Forskarutbildningens meritvärde. Betänkande av utredningen om forskningen och forskarutbildningens situation i nya högskolan

Regeringens proposition om forskning 1981/82:106 Om forskning

Regeringens proposition om forskning 1983/84:107

Regeringens proposition om forskning 1989/90:90

Regeringens proposition 1992/93:170 Forskning för kunskap och framsteg

SOU 1994:51 Minne och bildning: Museernas uppdrag och organisation

SOU 1995:84 Kulturpolitikens inriktning

Regeringens proposition 1996/97:5 Forskning och samhälle

SOU 2000:1 En uthållig demokrati! - Politik för folkstyrelse på 2000-talet

SOU 2009:15 Kraftsamling! - Museisamverkan ger resultat

Regeringens proposition 2009/10:3 Tid för kultur

SOU 2015:89 Ny museipolitik

Regeringens proposition 2016/17:116 Kulturarvspolitik

Forskningsproposition 2016/17:50 Kunskap i samverkan - för samhällets utmaningar och stärkt konkurrenskraft

Tabell 1. Ett urval av viktiga offentliga utredningar och politiska propositioner som påverkat relationen mellan forskning och museerna. 
och levandegöra kulturarv", skrivningar som senare återanvändes som mål för 1980-talets kulturmiljövård. Under det sena 1980-talet började kulturarv få en ny politisk roll. Det ledde fram till ett större utrymme för kulturarvsfrågor i svensk kulturpolitik och i 1996/97 års kulturpolitiska proposition infördes målet att "bevara och bruka kulturarvet" (s. 37). Under dessa decennier betonades som synes bevarande och brukande, snarare än det klassiska museets samlande och beforskande. I 2009/10 års proposition omformulerades målet något till att "kulturpolitiken ska främja ett levande kulturarv som bevaras, används och utvecklas" (s. 37). I ordet "utvecklas" går det att läsa in ett öppnande mot kunskapsuppbyggnad, även om inget explicit sägs om forskning. Det kan lika gärna tolkas som en referens till behovet av att utveckla och bredda kulturarvet för att göra det relevant $\mathrm{i}$ en mångfacetterad samtid och framtid.

Ur den ovan redovisade massan av utrednings- och propositionstext drar Johan Lund (2016) slutsatsen att det från det sena 1960-talet till mitten av 2010-talet var en tydlig, om än sällan rakt uttalad, politisk ambition att forskning skulle skötas av universiteten medan museerna skulle ägna sig åt kulturvård och folkbildning. Marginaliseringen av forskning inom museiinstitutionerna började redan på 1970-talet, och museibaserad forskning hade på 1980-talet förlorat mycket av sin politiska legitimitet. En besläktad utveckling syns i 1976 års beslut att låta länsstyrelserna ta över kulturmiljövårdsansvaret genom de nyinrättade länsantikvarierna.

Att organisera museerna utifrån deras vetenskapliga tillhörighet framstod som föråldrat i 1990-talet kulturpolitiska debatter. Istället fanns ett tryck på museerna att anpassas till att bättre fylla sin demokratiska roll (Lund 2016:158-163).

\section{MUSEERNA OCH VETENSKA PERNA}

Trots denna långa tendens har museernas interna organisation och samlingskategorier i hög grad hållit sig kvar vid traditionella vetenskapliga ordningar (Svanberg 2015b). Samtidigt har universitetens ämnen och utbildningar genomgått radikala förändringar sedan 1960-talet. Det har lett till att matchningen mellan museernas och akademins kunskapsordningar försvagats och i vissa fall helt förlorats. Under denna långa tid har politiken alltså inte tänkt på museer primärt utifrån en koppling till vetenskapliga fält. Samtidigt har en allt större del av personalen kommit att rekryterats utifrån andra kriterier och för andra uppgifter, mer kopplade till det demokratiska och folkbildande uppdraget än det kunskapsbärande. Utställningsproducenter, tekniker, pedagoger och kommunikatörer har vuxit fram som centrala professioner inom museerna (Lindqvist 2019).

Utvecklingen är dock inte helt entydig. Propositionen Utbildning och forskning: Kvalitet och konkurrenskraft (1993/94:177) bidrog, genom att slå fast att svensk uppdragsarkeologi skulle vara forskningsbaserad, till en utveckling som kom att stärka flertalet regionala museer i deras forskningskompetens. Forskare rekryterades och redan anställda fick möjlighet att doktorera. Detta bidrog till en hög forskningsnärvaro på museerna under första delen av 00-talet, kanske till och med den högsta i modern tid (Nilsson \& Rudebeck 2010). Men verksamheternas förutsättningar kom att ändras. Redan tre år senare föreslog propositionen Uppdragsarkeologi m.m. (1996/97:99) att uppdragsarkeologin skulle ingå i ett system av uppdragsbaserad och marknadsanpassad konkurrens. Fullt genomfört innebar detta att museernas arkeologiavdelningar bolagiserades, eller lades ner. Under den kommande 
tioårsperioden förlorade museerna därmed den höga närvaro av forskarkompetens som de byggt upp, vilket fått konsekvenser för hur forskning och kunskapsuppbyggnad i dag förstås på museerna (Högberg \& Fahlander 2017).

Riksbankens Jubileumsfond och Kungl. Vitterhets, Historie och Antikvitets Akademien finansierade 2002 Nordiska museets forskarskola som var ämnad att ge museianställda möjlighet att utveckla forskarkompetens (Rentzhog 2006) och dessa institutioner har fortsatt stödja forskning vid svenska museer, bland annat genom ett postdoc-program och utlysningen "Samlingarna och forskningen" 2015/16. Det har också funnits en kontinuerlig diskussion om, och argumentation för, forskningens plats inom museerna (Bohman 2000; DIK 2004; Björkman 2009; Lihammer 2009; Pettersson 2009; Svanberg 2011; Bäckström 2016; Laine 2018; Lindqvist 2019).

Förenklat kan vi ändå säga att det traditionella museet byggdes kring stabil sakkunskap organiserad i avgränsade fackfält. Sedan 1970-talet befinner sig museerna istället i ett gränsland där personliga erfarenheter varit väl så viktiga som vetenskapliga kunskaper. Inte minst i 1990-talets utredningar poängterades att demokrati är något som kräver ständigt deltagande, diskussion, förnyelse och förändring. Museerna hölls fram som institutioner där samtidens medborgare kunde bildas. Målet var alltså inte primärt att förmedla kunskaper utan att skapa reflektion och vad man lite hårdraget skulle kunna kalla för upplysta medborgare (jfr Bennett 1995). Den slags mer instrumentella kulturmål var framträdande i Miljöpartiets mycket omdiskuterade kulturprogram från 2015 - det som var ett av huvudmålen för Johan Lundbergs kritik i boken Det sista museet (2016) och för journalisten Ola Wong som drog igång museidebatten.

Instrumentaliseringen av kulturen har emellertid en lång historia. I 1974 års kulturpolitiska proposition återfanns målet "att motverka kommersialismens negativa verkningar inom kulturområdet”. Denna kulturpolitiska syn ledde bland annat till att kunskaper om hur museerna kan vara centrala aktörer för utvecklandet av lokal företagsamhet och entreprenörskap inte utvecklats i någon större utsträckning i Sverige, medan det i till exempel Italien varit ett framträdande kulturpolitiskt tema. Bland annat genom OECDs engagemang för den slags kulturpolitik har dessa frågor på senare år fått allt större plats även i Sverige (Grinell 2020).

För museidebattens kritiker framstod det som om erfarenheter, deltagande, normkritik och perspektiv helt hade tagit över museisverige, på bekostnad av mer traditionellt förevisande av föremål och förmedlande av kunskap (se exempelvis Hakelius 2017). Men så bara året efter lade den miljöpartistiska kulturministern fram den första kulturarvspolitiska propositionen någonsin (Regeringens proposition 2016/17:116).

\section{DEN SVENSKA MUSEILAGEN}

När Fredrik Linder, dåvarande chef för Kulturarv och Livsmiljö på Kulturdepartementet på återkommande möten runt om i landet presenterade den nya kulturarvs- och museipolitiken framhöll han att det fanns en "genomgående grundsyn att forskning och kvalificerad kunskapsuppbyggnad är grund för offentligt kulturarvsarbete."

Ur kulturarvspropositionen kom också Sveriges första museilag. Vad har den för implikationer för forskning och kunskapsuppbyggnadens roll i museerna? Låt oss citera de i sammanhanget viktigaste paragraferna i museilagen:

$4 \S$ Ett museum ska utifrån sitt ämnesområde 
bidra till samhället och dess

utveckling genom att främja kunskap, kulturupplevelser och fri åsiktsbildning.

6\$ Utställningar och annan publik verksamhet vid ett museum ska vara kunskapsbaserad och präglas av allsidighet och öppenhet.

$8 \S$ Ett museum ska bidra till forskning och annan kunskapsuppbyggnad, bland annat genom att ha hög kompetens inom sitt ämnesområde.

9\$ Ett museum ska aktivt förvalta sina samlingar för att nå verksamhetens mål.

Ordet kunskap förekommer fyra gånger i museilagens 12 korta paragrafer, två gånger i sammansättningen kunskapsuppbyggnad. Ordet forskning finns med på ett ställe. Utställningar nämns bara två gånger medan samlingar förekommer hela åtta gånger. "Kunskapsuppbyggnad" och "förvaltning av samlingar" får egna rubriker. Här finns väldigt lite av den aktivistiska kulturpolitik Miljöpartiet i synnerhet och museisverige i allmänhet kritiserats för. Istället framstår kunskapsuppbyggnad, aktiv samlingsförvaltning och publik verksamhet som nyckelord i museilagen.

Det är en kort text, 12 paragrafer om några få rader var. För att uttolka lagen behöver vi ta med kulturarvspropositionens resonemang kring lagtextens formuleringar och ordval.

\section{MUSEER, FORSKNING OCH KUNSKAPSUPPBYGGNAD}

I Kulturarvspropositionen 2016/17:116 konstateras att museerna på senare år fått ett breddat uppdrag "där förmedling och relationen till publiken satts tydligare i centrum än tidigare, samtidigt som vården av samlingar och den aktiva kunskapsuppbyggnaden fortsätter att vara lika viktiga som tidigare" (s. 88). Vidare betonar propositionen att "all utåtriktad verkkunskap. Det handlar dels om kunskap inom museets eget ämnesområde, dels om kunskap inom t.ex. förmedling och pedagogik" (s. 102). Museilagens $\$ 2$ talar om att museer ska vara öppna för allmänheten. Här ser vi att det inte handlar om att bryta med 90-talets demokrati- och folkbildningspolitiska museiuppdrag. Däremot poängterar man att denna breddning av uppdraget inte skulle ske på bekostnad av samlingsförvaltning och kunskapsuppbyggnad. Museerna uppfattas fortfarande ha egna sakämnesområden vid sidan av museologins generella kunskapsfält och kunskapsuppbyggnad ska förstås både "som en egen verksamhetsgren inom museiverksamheten och som en förutsättning för all verksamhet inom museet" (s. 103).

Det är slående hur all agens i lagtexten ligger hos museet. Museet förvärvar, bevarar, undersöker, förmedlar och ställer ut. Här har kulturarvspropositionens betoning av att kulturarv är något som människor själva skapar och gör hamnat i skymundan. Allmänheten måste släppas in genom dörrarna, men inte nödvändigtvis få påverka verksamhetsprocesserna. I $\$ 7$ upprepas att verksamheten ”ska vara tillgänglig för alla och anpassad till användarnas olika förutsättningar”. I den mån det, som museidebatten framställde det, finns en motsättning mellan delaktighet och kunskap så står lagen på kunskapens sida. Samlandet och dess potentiella funktion som en mellanställning i relation till denna möjliga motsättning diskuteras nästan inte alls (Nystrand von Unge 2019).

Det ställs "krav på att verksamheten ska vara öppen för olika vetenskapliga tolkningar och perspektiv", till exempel "genom att för allmänheten redovisa källor, museets skäl för olika urval och alternativa teorier, kan museet 
också hjälpa besökare och andra intressenter att göra sina egna bedömningar och bilda sig en egen uppfattning" (s. 102).

Det är skarpa formuleringar som ställer krav som få museiutställningar lever upp till. Samtidigt sägs inget i detalj om hur museet ska redovisa sina källor eller teoretiska utgångspunkter. Bör det kanske finnas fotnoter i utställningstexter, eller räcker det om källredovisning finns att få mot förfrågan eller i museets databas? Den kanske allra mest krävande skrivningen säger att museer ska ha "förutsättningar att följa relevant forskning samt tillämpa olika teoretiska perspektiv och tolkningsmodeller på verksamheten generellt” (s. 105). Här krävs en vetenskaplig hållning där museerna inte bara hänvisar till sin egen auktoritet som kunskapsinstitutioner utan faktiskt kan visa hur den dagliga kunskapsuppbyggnaden går till, liksom att den sker i relation till relevant forskning. Man ska också kunna motivera och förklara vilka urval varje utställning bygger på.

Museerna har dessutom till uppgift "att bidra till forskning och annan kunskapsuppbyggnad inom respektive ämnesområde", liksom "att upprätthålla nödvändig kompetens för att utföra ett kvalitativt arbete".

Vår tolkning är att det för en lagenlig kunskapsuppbyggnad inom museisektorn är nödvändigt att upprätta relationer till universitet och högskolor, både för museets egen verksamhet, och för möjligheten att främja och tillhandahålla förutsättningar för forskning och annan akademisk kunskapsuppbyggnad. Möjligheterna till sådana relationer är emellertid beroende av museernas lokalisering. Mindre museer på orter utan universitet eller högskolerepresentation verkar ha det mycket svårare att utveckla och upprätthålla sådana kontakter. En annan försvårande aspekt är att även större museer har svårt att budgetera för den medfinansiering som forskningsfinansiärer som exempelvis Vinnova eller KK-stiftelsen kräver för ansökningar för omfattande forskningsprojekt. Men oavsett premisser: enligt propositionen har alla museer ansvar för att skapa sig förutsättningar att följa relevant forskning inom sitt ämnesområde.

\section{FörUTSÄTTNINGAR FöR MUSEIFORSKNING I SVERIGE}

Regeringens proposition 2016/17:50 Kunskap i samverkan - för samhällets utmaningar och stärkt konkurrenskraft framhåller redan genom sin titel att forskning som sker i samverkan med aktörer utanför universitets- och högskolesektorn är viktig för att bidra till att identifiera samhällsrelevant och behovsmotiverad forskning och för att nyttiggöra forskningsresultat. Till skillnad från den tidigare politiska separeringen av forskning och museer styrs de bägge fälten nu mot ökad samverkan och ömsesidigt beroende.

- Hos de statliga forskningsfinansiärerna, och inom akademin i stort, finns ett ökat krav på samverkan. Detta sammanfaller med ett ökat samhällsvetenskapligt och humanistiskt intresse för praktisk och verksamhetsbaserad kunskap.

- Museilagen å sin sida har som vi sett ett starkt fokus på kunskap och samlingar. Det finns samtidigt ett stort behov av extern finansiering av museiverksamhet.

Det innebär att det borde finnas stora möjligheter att skapa den samverkan mellan museer och akademi som under lång tid saknat tydligt politiskt stöd. För att nå dit krävs en integrerad och strukturerad samverkan för gemensam strategisk kunskapsutveckling som kan skapa verksamhetsförankrad kunskap av hög vetenskaplig kvalitet. Konkret handlar det om 
att utveckla vetenskapliga teorier och resultat i samspel med praktisk verksamhet genom att forskningsanknyta praktiker och praktikanknyta forskning. Det sammantagna resultatet blir då mer än summan av enskilda bidrag. Därigenom kan en robust och kontextkänslig kunskap skapas, vars validitet prövas i dialog och med syfte att skapa förändring (Holmquist 2018).

För att nå dit finns ett behov av lokala mötesplatser och former för att matcha forskare och museer. För att museernas kunskapsuppbyggnad ska få bättre stadga och också bli lättare att matcha med den akademiska forskningens villkor och intressen är det viktig att säkerställa att ny kunskap byggs på befintlig kunskap som redan finns i forskningslitteratur, arkiv och databaser. Det är också avgörande att se till att all ny kunskap som byggs kommer in i databaser och arkiv och därigenom blir tillgänglig för externa forskare. Det kommer att behövas ett samlat politiskt grepp för att bygga upp ett sådant forskningsbaserat kunskapsutbyte i museisverige.

\section{MUSEERNA SOM AKTIVA KUNSKAPSINSTITUTIONER}

Museerna är kunskapsinstitutioner vars uppdrag består i aktiv samlingsförvaltning och publik verksamhet. Navet för att binda samman dessa bägge verksamheter och få dem att befrukta varandra är samlingskatalogen - den plats där information och kunskap om föremål och samlingar finns samlad (se Svanberg 2009 för diskussion). I dag måste hela samlingskatalogen vara digitaliserad och inlagd i en databas där informationen är säker, sökbar och lätt att uppdatera.

Alla som arbetar inom museet bör ges ansvar och tid att kontinuerligt föra in de nya kunskaper de utvecklar i databasen. Hela tiden måste det i metadata göras tydligt vilken slags uppgift det rör sig om, så att kunskapsuppbyggnaden bör hela databasen med digitaliserade 3D-bilder på föremålen ligga öppet online med någon slags wiki-funktion som tillåter dem som finner något där att lägga till ny information till föremålet, återigen med tydlig taggning och krav på att redovisa varifrån hen hämtar sin information.

Vid varje utställningsproduktion bör den kunskap som genereras registreras i databasen. Databasen kan också vara en aktiv del av varje utställning så att besökare i fördjupningsstationer, via QR-koder eller annan teknik lätt kan få fram de källor och perspektiv som legat till grund för hur föremål och tema presenteras i utställningen. Det kan vara ett sätt att, som Kulturarvspropositionen trycker på, göra museerna till mer öppna institutioner så de kan driva på samhällsutvecklingen genom att förmedla komplex kunskap om sina respektive ansvarsområden och skapa "en förståelse för att tolkning och omtolkning av vad som hör till kulturarvet ständigt pågår" (s. 58).

Det finns dessutom många sätt och arenor för att bruka kulturarv och förmedla kunskaper som inte är beroende av museilokaler, men som ändå kan använda museisamlingar. Med tekniska lösningar kan såväl förmedlingen av, och kunskapsuppbyggnaden kring, kulturarv och museiföremål återknytas till de platser som föremålen och historierna kommer från. VR, AR och andra digitala hjälpmedel kan sinnligt återskapa miljöer på plats (Gunnarsson 2018). Det ger möjlighet att uppfylla den samtida museologins ambitioner att vara där medborgarna är, och att låta museet ta plats utanför den egna byggnaden (Giannini \& Bowen 2019). Det gör det också lättare för museerna att vara där forskningen utförs och där vara den förmedlande länken mellan forskning och allmänhet. 
Här kan inspiration hämtas från exempelvis de samskapande arkeologiska projekt som genomförts sedan tidigare, i vilka olika former för dialog, deltagande och samskapande utforskande av det förflutna, samt av hur kunskapen om det förflutna skapas och förmedlas, undersöktes (Burström 1999; Högberg 2008).

En levande kunskapsinstitution bör skapa publika verksamheter kring det löpande kunskapsuppbyggnadsarbetet, istället för att vänta tills resultatet är färdigt, enligt principen: "Det här jobbar vi med nu". Så blir kunskapsuppbyggnaden till en tydligare del i museets dagliga arbete. Det kan också hjälpa museet att skapa en närmare dialog med lokalsamhället och besökarna som kan bli delaktiga i utforskandet, och därigenom för museet att möta propositionens ambition om att "Alla ska känna till att det kulturarv som museerna förvaltar tillhör dem” (s. 88). Det kan också göra det lättare att bjuda in forskare och utveckla ett samarbete som inte är beroende av en utställningsöppnings deadline.

\section{Acknowledgement}

Denna text är skriven inom ramarna för projektet "Forskning och kunskapsuppbyggande i samlingsförvaltning", finansierat av RAÄ FoU medel.

\section{REFERENSER}

Bennett, Tony 1995. The Birth of the Museum. London: Routledge.

Björkman, Jenny (red.) 2009. Bättre vetande. Ett symposium med anledning av den Hallwylska professurens 90-årsjubileum. Stockholm: Nordiska museet.

Bohman, Stefan 2000. "Museiforskning - onödigt eller nödvändigt?" I Tingen som kunskapskälla
- Om forskning på museer. Rapport från Statens kulturråd 2000:2, 14-19.

Burström, Mats 1999. "Kunskapssyn och arkeologisk förmedling." Kulturmiljövård 1/99. Stockholm: Riksantikvarieämbetet, 97-103.

Bäckström, Mattias 2016. Att bygga innehåll med utställningar: Utställningsproduktion som forskningsprocess. Lund: Nordic Academic Press.

DIK Museimannaförbundet, 2004. Tillbaka till gå? Enkätundersökning om forskning och forskarkompetens på museer. Rapport.

Giannini, Tula \& Jonathan Bowen (red.) 2019. Museums and Digital Culture. Cham: Springer.

Grinell, Klas 2020. Kulturens värde och sociala effekter. Rapport 2020:1. Göteborgs stad: Kulturförvaltningen.

Gunnarsson, Fredrik 2018. Archaeological Challenges, Digital Possibilities. Digital Knowledge Development and Communication in Contract Archaeology. Växjö: Linnaeus University Press.

Hakelius, Johan 2017. "Ideologi går före sakkunskap." I Kurt Almqvist \& PJ Anders Linder (red.), Museerna - klarar staten av sitt uppdrag? Stockholm: Axel och Margaret Ax:son Johnsons stiftelse för allmännyttiga ändamål, 55-63.

Holmquist, Mats 2018. Att utveckla en interaktiv samverkanskompetens. Samverkansformer. Nya vägar för humaniora och samhällsvetenskap. Lund: Studentlitteratur.

Hyltén-Cavallius, Charlotte \& Fredrik Svanberg 2016. Älskade museum. Svenska kulturhistoriska museer som kulturskapare och samhällsbyggare. Lund: Nordic Academic Press.

Högberg, Anders 2008. "Community Archaeology en samskapandets arkeologi." I Mats Burström (red.), Arkeologi i förorten. Berättelser från norra Botkyrka. Södertörn Archaeological Studies. Södertörns högskola, 119-140.

Högberg, Anders 2016. ”Museidebatt med åsikter utan vetenskapligt stöd." Respons, no. 6. 14-16.

Högberg, Anders \& Fredrik Fahlander 2017. "The 
Changing Roles of Archaeology in Swedish Museums." Current Swedish Archaeology 25, 13-19.

Laine, Anna 2018. Museiforskning. En översikt. Stockholm: Riksantikvarieämbetet.

Lihammer, Anna 2009. Forskningen vid svenska ABM-institutioner: En undersökning av aktuella förutsättningar och trender, Stockholm: Nobelmuseet.

Lindqvist, Katja (red.) 2019. Kompetens i museisektorn. Politik, praktik och relation till högre utbildning. Lund: Nordic Academic Press.

Lund, Johan 2016. Museet vid Korsvägen. Göteborg: Göteborgs universitet (diss).

Lundberg, Johan 2016. Det sista museet: Reflektioner om identitetspolitik, kultur och integration. Stockholm: Timbro.

Nilsson, Björn \& Elisabeth Rudebeck 2010. "Arkeologiska världar." I Björn Nilsson \& Elisabeth Rudebeck (red.), Arkeologiska och förhistoriska världar: Fält, erfarenheter och stenåldersplatser i sydvästra Skåne. Malmöfynd 19. Malmö: Malmö Museer, 11-82.

Nystrand von Unge, Elin. 2019. Samla samtid: Insamlingspraktiker och temporalitet $p a ̊$ kulturhistoriska museer i Sverige. Stockholm: Stockholms universitet (diss).

Näsman, Olle 2014. Samhällsmuseum efterlyses. Svensk museiutveckling och museidebatt 1965-1990. Umeå: Umeå universitet (diss).

Pettersson, Richard 2009. "Museerna och forskning." Nordisk Museologi 2, 110-129.

Regeringens proposition 1993/94:177 Utbildning och forskning: Kvalitet och konkurrenskraft.

Regeringens proposition 1996/97:5 Forskning och samhälle.

Regeringens proposition 1996/97:99 Uppdragsarkeologi m.m.
Regeringens proposition 2009/10:3 Tid för kultur.

Regeringens proposition 2016/17:50 Kunskap i samverkan - för samhällets utmaningar och stärkt konkurrenskraft.

Regeringens proposition 2016/17:116 Kulturarvspolitik.

Rentzhog, Sten 2006. Forskning \& museer: En debattskrift om museernas behov av kunskap och forskningens behov av museer. Stockholm: Nordiska museets förlag.

Svanberg, Fredrik 2009. Museer och samlande. Stockholm: Historiska museet.

Svanberg, Fredrik (red.) 2011. Forskning vid museer. Stockholm: Historiska museet.

Svanberg, Fredrik 2015a. Människosamlarna. Anatomiska museer och rasvetenskap i Sverige 1850-1950. Stockholm: Historiska museet.

Svanberg, Fredrik 2015b. "The world as collected; or museum collections as situated materialities." I Andrea Witcomb \& Kylie Message (red.), The International Handbooks of Museum Studies: Museum theories. London: Wiley Blackwell, 389-415.

Klas Grinell, docent i idéhistoria. Föreståndare för Centrum för Europaforskning vid Göteborgs universitet och kulturstrateg vid Kulturförvaltningen, Göteborgs stad. klas.grinell@kultur.goteborg.se

Anders Högberg, professor i arkeologi. Institutionen för kulturvetenskaper, Linnéuniversitetet. Verksam inom Centrum för tillämpat kulturarv och Unesco Chair on Heritage Futures. anders.hogberg@lnu.se 